\title{
Codes and Conducts of Food Eating - A Scientific Review
}

\author{
${ }^{* 1}$ Waghmare P. , ${ }^{2}$ Umarkar S. , ${ }^{3}$ Vyas D. \\ ${ }^{1}$ Associate Professor, Sanskrit Samhita Siddhanta Department, Government Ayurved College, Nagpur. \\ ${ }^{2}$ Assistant Professor, Department of Kriya Sharir, Government Ayurved College, Nagpur. \\ ${ }^{3}$ Associate Professor Department of Kriya Sharir, Jupiter Ayurved Medical College, Nagpur.
}

\begin{abstract}
Today the whole world is suffering from many diseases related to changed food style and the ways of eating food. The symptoms and diseases like overweight, obesity and Diabetes mellitus are some of the tips of icebergs of diseases. Ayurveda faiths on food as the major drug of diseases, 'Mahabheshaj.' Solely food can cure diseases. But this food is to be cooked and consumed properly, even intake of food sometimes becomes a reason of diseases. So , each and every person should understand the code and conducts of food cooking and food eating. To cook food, to consume it is indeed a science. It has to be followed. Vedas have great faith that Jatharagni residing in human body is the holy fire as that like yajna and aahar is havi which is to be offered to Jatharagni to maintain human body, mind and soul. For the nourishment of Saptadhatus of human body proper aahar be consumed. As proper and in quantity food gives strength and life to us and vice versa. Charak Samhita plays a vital role in describing codes and conducts of food cooking and food eating which are the same authentic in today's era also.
\end{abstract}

Keywords : Mahabheshaj, Jatharagni, Yajna

\section{Introduction}

Ayurveda, the science of life mentions aahar, nidra and brahmacharya are its tripod of life. ${ }^{(1)}{ }^{(2)}$ Out of these aahar stands first. One may get confused over the word 'food culture of Ayurveda', but it is true that Ayurveda along with dietetics of a person describes food culture also. Now a days many of us do not get adequate time to have our meals. We eat by running, walking or speaking on a mobile. Eating by watching television is a very common feature of today's fast life. This changed food culture is one of the basic causes to many of the diseases and we are paying for it. We are facing the same through our changed food culture and habits. Agnimandya, aruchi, ajeerna, amlapaitta, sthaulya, karshya are the results of changed food culture.

Ayurveda has great faith that the sacred Agni hosts human body also. This sacred Agni is like an enlighten yajna and as a 'Hota' sacrifices ghrut to remain yajna enlightened, one should sacrifice holy aahar to the sacred Agni situated in our stomach to remain it enlightened. ${ }^{(3)}$ Being stimulated by the Antaragni, Agnis digest the various types of wholesome eatables, beverages, linctus food articles producing thereby plump less, strength , complexion and happiness as well as growth of the tissue elements of the entire body. Where the process of metabolism goes on incessantly like the passage of time and where all the Dhatvagnis, Vata and channels of circulation are unimpeded. The tissue elements of the body are sustained being fed by their nourishing factors. This enlightened Agni will digest the holy aahar and dhatus will be nourished. ${ }^{(4)}$ Nourishment of dhatus make a healthy body, mind and soul. So, Ahar plays an important role in maintaining good health. The intake of unwholesome food as well as doshas and the physical constitution gives rise to diseases of many types, viz ., mild or severe and acute or chronic. ${ }^{(5)}$

Aims

To evaluate the importance of food in maintaining and balancing human body, mind and soul.

Objectives

To understand various techniques to cook food scientifically.

To learn the food eating culture i.e. codes and conducts of food eating 
${ }^{1}$ Waghmare P., International Journal of Ayurvedic \& Herbal Medicine 7(4) July.-Aug. 2017 (2774-2778)

\section{Materials and Methods}

A critical review of Samhita's was carried out. All literary references were collected from Samhitas.

\section{Importance of Food}

Food sustains the life of living beings. All living beings in the universe require food. Complexion, clarity, good voice, longevity, geniuses, happiness, satisfaction, nourishment, strength and intellect are all conditioned by food. Professional activities leading to happiness in this world, Vedic rituals leading to abode in heaven and observance of truth Brahmacharya leading to salvation are all based on food. ${ }^{(6)}$

The best medicine is food. Just by giving proper food one can be cured. Even medicines seek shelter of food. So food be termed as 'Mahabhaishajya'. (7)

Cooking food An Art as well as Science

Ayurveda does not only advices us on eating habits but also on the cooking procedures of it. Charak Samhita's Vimanasthana deals with the minute study of dosha, drugs, locality, season, strength, physique, excellence of dhatus, diet, homologation, mind, constitution and age. (8) Regarding diet 'Aushtauaaharvidhivisheshayatanani' word itself defines self-sense. Ashta means eight, aaharvidhi procedure in cooking food, vishesh ayatanani - special places or houses. These are eight special aspects in the procedure of cooking food. They are-

Prakriti - Prakriti is nature. Each and every raw material is having its own qualities. One should keep in mind that the thing which we are eating will work on our body by its inherited properties. Prakriti of an eater and prakriti of a food should match each other properly or else it will lead to diseases. Like if a fat person consumes Masha lentils and flesh, it will increase his fattiness and cause kaphaprakop. He should better opt Mudga lentils.

Karan - Karana is transformation of gunas from one to another or to raise the capacity of original gunas. Water, heat, cleaning, churning, place, time, special utensils work as an instrument to karan causing alteration . Ex. - Dadhi is abhishyandi, but after churning it becomes takra which is highly agnivardhak.

Samyog - Samyog is a combination. Sometimes combining two dravyas do a great work than singly. Or it may be sometimes hazardous. Proper quantity of dravyas leads a main role. Ex- same quantiy of ghee and honey are poisonous but if taken unequally work miraculously.

Rashi - Rashi is quantity. The quantity of food we consume at once or in a day decides wellness and illness of our body.

Desha - One should always think of place of food i.e. origin of a food stuff which he is consuming. Because desha also plays a role on qualities of that particular grain or fruit or vegetable. Drugs and vegetables of an anuppradesh inherit guru quality while that of a desert inherits ruksha quality. If a person residing in jangalpradesh consumes anup pradesh food it will not suit him and vice versa.

$\mathrm{Kal}$ - Consumption of food according to kala has a special attention. Rutucharya explains it better. This may lead to 'yamadanshtra'. So consuming food according to kala though nityag or avasthik is a wise decision. Upayogasanstha - It is the rules and regulations, codes and conducts of aaharsevan.

Upayokta - Upayokta is a person who consumes food. It is the last but the most important factor of 'Ashtauaaharvidhivisheshayatanani'. Upayaokta should be dnyata. He should know his condition of Agni, doshprabhav, manas avastha and also the quality and quantity of food. Then only these aayatanani will work. As in Chikitsachatushpad vaidya leads a main role likewise in 'Ashtauaaharvidhivisheshayatanani' upayokta leads a main role. Samanaska upayokta makes aaharsevan successful. ${ }^{(9)}$

\section{Codes and conducts of food eating}

To consume scientifically cooked food in a proper way also plays an important role in maintaining health or else its mere stomach filling. There are some codes and conducts of food eating which include how to eat and how to not.

\section{One should not eat}

- Not wearing precious stones in hand

- Without bathing

- Without worshipping the deity

- Without wearing clean clothes 
- Without feeding parents, teachers, dependents and guests

- Without cleaning face, hands and legs

- In dirty utensils

- Untimely

- In a crowd

- Without sacrificing to Agni

- Without recitation of mantras

- Unpleasant place

- One should leave something in a platter after meals except Dadhi, Madhu, Lavan, Sattu and Ghee. Now a days we say that to leave food in a plate after meals is a bad manner, but at that time the plates were of banana leaves or big leaves. So to leave something on then is to feed small insects. It is nothing but a code to feed each and every creature of this world.

- One should not eat curd at night.

- One should not eat excess of water after meals and also during meals ${ }^{(10)}$.

\section{How to eat?}

1. One should eat hot, unctuous food in proper quantity i.e. one portion of stomach for food, one for liquids and one for the movement of doshas. Ushna and snigdha bhojana increases taste of food, enlightens Agni, digests food, it helps to pass flatus, increases strength, vigor, beauty and health.

2. One should eat at that time only when previous food is digested, as overeating leads to agnimandya which causes aam and thus welcomes many diseases. Excess intake of food disturbs vata-pitta-kapha balance leading to Ajeerna, Medoroga, Alasak, Visuchika, Jvar, Atisar, Shool and Aanah. Food taken in a proper quantity gets digested easily and Agni works with a great strength.

3. Combination of two's having different veeryas names potencies i.e. working actions should not be consumed.

4. One should have meals in pleasant place with all preparations. Pleasantness calms down mind and hence good digestion occurs.

5. One should not take meals in a hurry. Food taken slowly, hurriedly, talking, laughing disturbs digestion. One may overeat or may remain hungry or the food may enter wind pipe causing coughing.

6. One should eat wholeheartedly by examining himself properly. ${ }^{(11)}$ (Jeernajeernanirupayana)

7. Ayurveda does not allow anybody for hard core dieting, though in the treatment of santarpanajanya vyadhi upavas is one of the options of Ayurveda. But that is also up to a mark. Charakacharya explains hazards of eating less quantity of food. It may lead to death also. Isn't it an eye opener for those who go on a harsh dieting to lose weight or to get a so called beauty? ${ }^{(12)}$

8. One should not have meal by holding natural urges.

9. The sequence of tastes in meal should be like this. Madhur (sweet), guru (heavy), snigdha (unctours), manda and Sthir food be consumed at first. Then Amla rasa be consumed. The meal should sum up with all remaining tastes and qualities opposite to first one. ${ }^{(13)}$

Ayurveda defines codes and conducts of food eating along with balanced diet. The one who understands these small but important facts becomes healthy, fit and happy. One desirous of wellbeing in this world and the world beyond, should try his level best to follow the principles of health relating to diet, conduct and action. ${ }^{(14)}$

To receive the better benefits of the Ahara it is also necessary to have knowledge about 'Ashtauaaharvidhivisheshayatanani' ${ }^{(15)}$. Healthier eating habits may help lower risk for typer II diabetes , heart disease, stroke, cancer, infertility and many other health problems. ${ }^{(16)}$ Not only diet but also the method of diet intake has important role in the continuity of healthy life. ${ }^{(17)}$

\section{Discussion}

The eight special aspects in cooking food plays an important role. Today, whole new generation is in the grasp of fast food. This junk food of no nutrition value leading the generation to various diseases making an alarming condition. Obesity, diabetes, hypertension, loss of appetite are just the tip of icebergs of diseases. 
Many more are on its way. In such conditions these eight special aspects prove scientifically as proper cooking methods. 'Know yourself' is the first key to food success. Eating by knowing self and qualities of food is most important. That is Prakriti. Likewise Karan, Sanyog are the techniques to cook food scientifically. These actions purify, clean and makes the food healthier and easy to digest. Rashi (quantity of food), Desha(place) and Kala(time) are solely independent variables. Upyogsantstha is the real code and conduct of food eating. Upayokta is self who follows Upayogsanstha and knows self.

Ayurveda, pays a lot of attention to cleanliness and hygiene while food cooking and consuming. That is why it emphasizes on personal hygiene as well as hygiene of the place where food is to be consumed.

It advices a person to have meal after pacifying all the members of family and family includes even cattle grazing in the backyard. It suggests us our social as well as personal duties in society.

Eating hurriedly is one of the causes of indigestion and other diseases. Today, we eat food just to fill the stomach cavity without paying attention to this basic rule.

In a meal sweet food items be consumed first. Because if such items are eaten first the enlightened Agni of our stomach can easily digest that heavy food. Then Amla rasa, which is Agni elevator will increase the fire. Finally all other rasas be consumed as they need less power to digest the food. This is a very scientific method to consume meal. This method is drawn in keeping Agni on forefront.

\section{Conclusion}

Food eating is just not a habit but it's a culture and that culture is to be followed thoroughly. This culture of food eating has some codes and conducts which are integral part of it. It not only makes us understand how to eat but also makes us aware about social and personal etiquettes of food eating. Codes and conducts of food eating is certainly a strong scientific method of consuming food keeping in mind the power of holy fire in our stomach.

\section{References}

1. Agnivesh, Charak, Drudhabala. Trisraieshaneeyamadhyay. In Chowkhambha Sanskrit Series Office, editor. Caraka Samhita. 6th ed. Varanasi: Chowkhambha Sanskrit Series Office; 1999. p. 219.

2. vagbhat. Annarakshaadhyay. In Dr. Tripathi B. Ashtanghridayam. Delhi: Chaukhamba Sanskrit Pratisthan; 2014. p. 129.

3. Agnivesh C,D. Annapanvidhimadhyay. In Sharma RK, Dash B. Caraka Samhita. 6th ed. varanasi: Chowkhamba Sanskrit Series Office; 1999. p. 564.

4. Agnivesh CD. Vividhasheetpitiyamadhyay. In Sharma RK, Dash B. Caraka Samhita. 6th ed. Varanasi: Chowkhamba Sanskrit Series Office; 1999. p. 566.

5. Agnivesh CD. VividhasheetpitiyamAdhyay. In Sharma RK, Dash B. Caraka Samhita. 6th ed. Varanasi: Chowkhamba Sanskrit Series Office; 1999. p. 574.

6. Agnivesh C,D. Vividhaseetpitiyamadhyay. In Sharma RK, Dash B. Caraka Samhita. Varanasi: Chowkhamba Sanskrit Series Office; 1999. p. 565.

7. Vrudhhajeevak. Yushnirdesheeyadhayay. In Tewari PV. Kasyapa Samhita. Varanasi: Chaukhamba Vishwabharati; 1996. p. 468.

8. Agnivesh, Charak, Drudhabala. Rasaviman. In Sharma RK, Dash B. Caraka Samhita. Varanasi: Chowkhamba Sanskrit Series Office; 2000. p. 112.

9. Agnivesh CD. Rasavimanadhyay. In Sharma RK, Dash B. Caraka Samhita. Varanasi: Chowkhamba Sanskrit Series Ofice; 2000. p. 123-127.

10. Agnivesh C,D. Indriyopakramaniyamadhyay. In Sharma RK, Dash B. Caraka Samhita. 6th ed. Varanasi: Chowkhamba Sanskrit Series Office; 1999. p. 175.

11. Agnivesh C,D. Rasavimanadhyay. In Sharma RK, Dash B. Caraka Samhita. 6th ed. Varanasi: Chowkhamba Sanskrit Series Office; 2000. p. 127-131.

12. Agnivesh CD. Langhanbrumhaniyamadhyay. In Sharma RK, Dash B. Caraka Samhita. 6th ed. Varanasi: Chowkhamba Sanskrit Series Office; 1999. p. 392.

13. Waghmare P. Ashtanghrudaypranit Aaharcharcha. In. Nagpur: Shri Renuka Prakashan; 2015. p. 29. 
14. Agnivesh, Charak, Drudhabala. Navegandharaniyamadhyay. In Sharma RK, Dash B. Caraka Samhita. Varanasi: Chowkhamba Sanskrit Series Office; 1999. p. 161.

15. Savanur PV. Adaptation of Ashta Vidhi Vishesha Ayatana in Today's Life Style. International Journal of Applied Ayurved Research. 2015 July-Aug; II(II).

16. Sharma D, Vishwakarma P. Scientific Explanation of Charak's Ahara-Vidhi Vidhan (Dietary Guidelines). International Ayurvedic Medical Journal. 2015 March; III(III).

17. Singh A, Singh KB, Singh P, Sharma S. Ahara Vidhi (Dietetics) : Concepts of Food Intake In Ayurveda. Unique Journal of Ayurvedic And Herbal Medicines. 2015 July-August; III(IV): p. 47-53. 